\title{
Corporate Governance in Latin America: Towards Shareholder
} Democracy

\author{
Ruth V. Aguilera, Northeastern University, USA \\ Rafel Crespí-Cladera, Universitat de les Illes Balears, Spain \\ Luiz Ricardo Kabbach de Castro, University of São Paulo, Brazil, and Universidad \\ de Navarra, Spain
}

How can Latin American majority shareholders keep their corporate control? Shareholder democracy, the idea that "oneshare equals one-vote" and that firms are controlled by shareholders who exercise their power with equal economic rights, has recently gained great attention in corporate governance debates. This is particularly because technology companies such as Ebay or Facebook have founders who control a lot more than they own via dual class shares, some companies such as social media Snap listed with shares with no voting rights, and stock exchanges such as Hong Kong Stock Exchange changed listing regulations to prevent losing future technology companies such as Alibaba.

The advocates of shareholder democracy sustain that aligning the economic rights and voting power of controlling shareholders may increase their incentives to maximize the value of the firm (i.e., value for all shareholders) while simultaneously reduce the potential incentives for private benefits of control (i.e., value only for controlling shareholders at the expense of minority shareholders). Hence, shareholder democracy is a key element of corporate governance systems to protect outside investors, and consequently, to facilitate the development of the supply-side of capital, through equity.

Dual-class shares where one share does not equate to one vote jeopardize shareholder democracy and might exacerbate an agency problem between large (controlling) shareholders and minority investors. In part, this is because the dual-class shares do not generate any direct competitive advantage to the company, but clearly intensify potential moral hazard concerns by increasing the difference between largest shareholder economic (cash flow) and control rights. In this article, we discuss the role of the dual-class share mechanism as vehicle to enhance control, and its implications for economic outcomes in emerging economies.

\section{Institutionall Voids and Corporate} Governance

Emerging markets are best defined by structural deficiencies due to institutional voids (Gao et al., 2017). When these institutional structures are absent or weak, governance deteriorates, corruption escalates, uncertainty increases, and instability emerges; all of which exacerbate institutional constraints to mutually productive exchanges. Although Latin America countries clearly present significant institutional differences, there also exist a set of common factors including development of the economy, capital markets, and other institutions. Table 1 shows some of the structural dimensions of selected Latin American economies compared to the U.S. and OECD countries. It is worth noting that there is a pattern toward institutional voids, which harms the economic exchange within a country and across its borders. Inefficient judicial systems, the lack of creditors and shareholders protection, high levels of corruption, and high costs of cross-border transactions are examples of institutional factors affecting firms' decisions and outcomes. It is easy to conclude from this snapshot that there are structural challenges, a common denominator in emerging economies.

Corporate governance is concerned with distributing rights and responsibilities among different stakeholders (Aguilera \& Jack- 
son, 2003) in order to minimize conflicts of interest, allocate resources efficiently, and enhance transparency and accountability. Again, corporate governance in the Latin America is by no means uniform, but there are common institutional characteristics across countries. Mierta Capaul (2003), Chief Economist of the Word Bank for Latin America and the Caribbean Region, described three main corporate governance features: French civil law origin, the ubiquitous presence of large concentrated shareholders, and family business groups ("grupos de negocios"). Between her findings and the Table 1 current data, there is a gap of 15 years with little real structural change in corporate governance institutions supporting economic growth.

Latin American countries, therefore, do not seem to be converging toward the Anglo-American corporate governance model characterized by strong shareholder rights, high transparency, relatively open CEO labor markets, and external markets for corporate control. Latin American countries are more akin to traits of the internal corporate governance mechanisms that characterize emerging markets. That is, ownership concentration, business groups, insider boards of directors, and information asymmetries (Aguilera et al., 2012; Aguilera \& Haxhi, 2019). In part, these firms' governance and strategic decisions are influenced by a country's institutional voids, weak minority shareholder rights, and underdeveloped stock markets (Khanna $\&$ Palepu, 2010). As such, a chicken and egg scenario exists.

\section{Is There Shareholder Democracy in Latin America?}

It is worth noting that the dual-class share governance mechanism is spread around the world (Kim, Matos, $\& \mathrm{Xu}, 2018$ ). In Latin America, following the period of liberalization in the late 1980s, despite the shift from state to private hands through the privatization process of state-owned firms and market-oriented reforms, many governance practices persisted including high ownership concentration in the hands of domestic business groups and the practice of dual-class shares. Chong and Lopez-de-Silanes (2007) describe the ownership structure of the largest companies in six Latin American countries to show that not only is the ownership highly concentrated in the largest shareholder, but also that there exists a significant separation of ownership and control in Latin American corporations. This is accomplished through two control-enhancing mechanisms: dual-class shares and pyramidal business groups (see Perkins [2019] in this special issue).

\section{Table 1. Institutional variables in selected Latin American countries, the United States, and OECD countries}

\begin{tabular}{|c|c|c|c|c|c|c|c|}
\hline Economy & Brazil & Chile & Colombia & Mexico & Peru & $\begin{array}{l}\text { United } \\
\text { States }\end{array}$ & $\begin{array}{l}\text { OECD } \\
\text { High } \\
\text { Income }\end{array}$ \\
\hline Starting a Business - Procedures (number) & 11 & 8 & 8 & 7.8 & 8 & 6 & 5 \\
\hline Starting a Business - Time (days) & 82.5 & 7.5 & 11 & 8.4 & 41.5 & 5.6 & 9.4 \\
\hline Starting a Business - Cost (\% of income per capita) & 5.2 & 5.9 & 14.1 & 17.8 & 9.9 & 1.1 & 3.7 \\
\hline Getting Credit - Strength of legal rights index $(0-12)^{1}$ & 2 & 4 & 12 & 10 & 7 & 11 & 6 \\
\hline $\begin{array}{l}\text { Protecting Minority Investors - Strength of minority investor protec- } \\
\text { tion index }(0-10)^{1}\end{array}$ & 6.5 & 6 & 8 & 5.8 & 6 & 6.5 & 6.4 \\
\hline Score-Trading across borders ${ }^{2}$ & 58.79 & 80.56 & 61.83 & 82.09 & 68.22 & 92.01 & 93.8 \\
\hline $\begin{array}{l}\text { Trading across Borders - Cost to export: Documentary compliance } \\
\text { (USD) } 2\end{array}$ & 226.4 & 50 & 90 & 60 & 50 & 60 & 36.3 \\
\hline $\begin{array}{l}\text { Trading across Borders - Cost to import: Documentary compliance } \\
\text { (USD) } 2\end{array}$ & 106.9 & 50 & 50 & 100 & 80 & 100 & 29.5 \\
\hline Trading across Borders - Cost to export: Border compliance (USD) 2 & 862 & 290 & 630 & 400 & 630 & 175 & 146.2 \\
\hline Trading across Borders - Cost to import: Border compliance (USD) 2 & 821.7 & 290 & 545 & 450 & 700 & 175 & 111.5 \\
\hline Enforcing Contracts - Time (days) & 731 & 480 & 1288 & 340.7 & 426 & 420 & 570 \\
\hline Enforcing Contracts - Cost (\% of claim) & 22 & 25.6 & 45.8 & 33 & 35.7 & 30.5 & 21.7 \\
\hline Enforcing Contracts - Quality of the judicial processes index $(0-18)$ & 13.1 & 9 & 9 & 10.1 & 8.5 & 13.8 & 11.0 \\
\hline Corruption Perception Index (Rank 1 to 180 ) & $37(96)$ & $67(26)$ & $37(96)$ & $29(135)$ & $37(96)$ & $75(16)$ & - \\
\hline
\end{tabular}

Source: http://www.doingbusiness.org, Doing Business Report, 2017; Corruption Perception Index from https://www.transparency.org/news/feature/corruption_perceptions_index_2017

1: DB15-19 methodology, 2: DB16-19 methodology, 3: DB16 methodology. 
Table 2. Voting rights and dual-class shares of the largest shareholder across countries.

\begin{tabular}{lcccc}
\hline Country & $\begin{array}{c}\text { Number } \\
\text { of Firms }\end{array}$ & $\begin{array}{c}\text { Mean Voting } \\
\text { Rights (\%) }\end{array}$ & $\begin{array}{c}\text { Standard } \\
\text { Deviation (\%) }\end{array}$ & $\begin{array}{c}\text { Dual-Class Shares } \\
(\%)\end{array}$ \\
\hline Brazil & 269 & $48.5(53.7)$ & $26.0(25.0)$ & 50.9 \\
Chile & 130 & $42.9(42.7)$ & $25.5(26.8)$ & 7.6 \\
Colombia & 25 & $39.1(60.0)$ & $26.2(16.9)$ & 5.7 \\
Mexico & 93 & $38.6(35.3)$ & $25.1(26.5)$ & 28.6 \\
Peru & 104 & $54.8(54.4)$ & $28.6(28.2)$ & 52.3 \\
\hline Total & 621 & $46.7(51.5)$ & $26.8(26.7)$ & 37.9 \\
\hline United States ${ }^{1}$ & $6,707^{2}$ & $61.8^{3}$ & - & 6 \\
\hline European firms & 493 & $46.0(46.0)$ & $24.0(24.0)$ & 29 \\
\hline
\end{tabular}

Notes: In parentheses, we report the average voting rights for dual-class firms to compare with the U.S. sample from Gompers et al (2010).

1. Gompers, Ishii, and Metrick (2010: 1057).

2. This data refers to the year 2002 (see Table 1, Gompers et al., 2010).

3. This data refers to dual-class firms.

4. Maury and Pajuste (2011: 362), this data refers to 2005.

Using a sample of 621 (6,253 firm-year observations) non-financial firms (i.e., excluding banks and insurance companies) publicly listed in five Latin American countries from 2003 to 2017, we show in Table 2 that there is low shareholder democracy in Latin America ${ }^{1}$ and that the presence of dual class shares is widely spread, relative to other countries in the world. The largest shareholder holds, on average, $46.7 \%$ of voting rights, and more than one third of the firms use dual-class shares to enhance their controlling positions. In Brazil, for example, the controlling shareholder of Suzano Holding S.A., who controls Suzano Pulp Mills, holds $87.54 \%$ of the voting rights and only $35.69 \%$ of economic rights. This separation is mainly due to the existence of dual-class shares.

Advocates for dual-class shares argue that founders and entrepreneurs can retain control of a company to implement their longterm plans or value creating idiosyncratic vision. From a market perspective, dual-class shares allow investors to select the shares that better suit their preferences. Even assuming higher cost of capital, these companies can finance their expansion taking advantage of public markets with the benefits of private companies.

This enhanced shareholder control deters the myopic focus on short-term yield which imposes short-term earnings reports, allowing discretionary power for long-term investments. Yet the effect varies depending on the type of large shareholders across different countries. For example, when a firm's largest shareholder is an individual or a family, it is likely that, in order to keep family control or to guarantee the firm succession in the hands of future generations, they may seriously consider leveraging its control position through dual-class shares. Governments as largest shareholders may strengthen their voting power for strategic interests such as monopolies (i.e., oil and gas, or utilities) or use the dual class shares control-enhancing mechanism to resist takeover bids, while industrial firms may retain control to develop internal capital markets through business groups. This tradeoff is particularly salient in emerging markets, where the underdeveloped institutional environment makes controlling structures an efficient response to reduce the cost of transacting in the market (Khanna \& Palepu, 2010).

Considering that different controlling shareholders may diverge in their interests towards firms' decisions and outcomes, in Table 3, we report differences of the largest shareholder voting rights between firms with and without dual-class shares across different largest shareholders types. It is worth noting that the only type of shareholder that does not use the dual-class mechanism is "institutional investors" (i.e., mutual and pension funds). This is because they are not typically directly related to the management of the firm; instead, they work as a strategic partner with patient capital, where long-term performance is desirable.

\section{What Are the Consequences of Shareholder Autocracy?}

We still do not have a final answer whether shareholder autocracy - the presence of a large shareholder with strong power 
under firms' decisions - is, per se, good or bad for firms' value. However, we do know that some governance mechanisms are more likely to entrench majority shareholders, such as dual-class shares, and consequently significantly reduce the ability of minority shareholders to have a say on firms, particularly, in times where managerial decisions are not sound and the institutional setting precludes outside investors to enforce their rights. See, for example, the recent Brazilian corporate scandal that affected Petrobras, the largest oil company in Brazil, where the largest shareholder is the Brazilian government. The American investors who invested in Petrobras ADRs (American Depositary Receipts) in the NYSE were able to sue the company to claim their rights, while the Brazilian investors, most of them with preferred shares (i.e., with no voting power and preference in cash outs), were left behind.

At the same time, Gao et al. (2017) argue that family business groups in emerging economies, such as the Tata Group in India, Koç Holdings in Turkey, and Grupo Bimbo in Mexico, all under a shareholder autocracy lead by control-enhancing mechanisms, have been able to survive and expand, delivering value for the family controlling shareholder and their other stakeholders. They propose that the main driver for the "incen- tive effect" in those firms is reputation. Reputation is strongly related to the long-term perspective of business groups and their controlling shareholders. Therefore, in the presence of shareholder autocracy in emerging economies, investors may look at the level of commitment of the largest shareholder towards a firm's reputation and long-term results.

For policymakers, fostering and encouraging firms to develop a long-term perspective where shareholders and stakeholders can base their relationship on mutual trust, transparency, dia$\log$, and respect is worth taking. This implies developing better safeguard mechanisms for minority (non-controlling) shareholders other than ownership mechanisms. Examples include: third-party arbitration for conflicts of interests, greater dialog between entrenched boards and investors that reduce the cost of minority investors to access information and increase their incentives to commit for the long-term, more transparency in the decision-making process through a sound and procedural decision-making policy, responsible remuneration policy for entrenched managers (government officials or family members) that is aligned to company's mission and values, and clearly linked to the successful delivery of the long-term strategy.

Table 3. Voting rights of the Largest Shareholder for Dual-class and non-dual-class shares firms.

\begin{tabular}{|c|c|c|c|c|c|c|}
\hline Panel A. Largest Shareholder Typology & Stats & Non-Dual-Class Shares & Dual-Class Shares & Total & Difference & p-value \\
\hline \multirow[t]{3}{*}{ Corporate } & $\mathrm{N}$ & 1,944 & 1,360 & 3,304 & & \\
\hline & Mean & 49.99 & 55.35 & 52.2 & 5.36 & 0.000 \\
\hline & $\mathrm{SD}$ & 25.22 & 24.54 & 25.08 & & \\
\hline \multirow[t]{3}{*}{ Banks, Insurance, and Other Financial Firms } & $\mathrm{N}$ & 1,037 & 415 & 1,452 & & \\
\hline & Mean & 37.76 & 47.38 & 40.51 & 9.62 & 0.000 \\
\hline & SD & 24.02 & 27.04 & 25.29 & & \\
\hline \multirow[t]{3}{*}{ Families } & $\mathrm{N}$ & 344 & 286 & 630 & & \\
\hline & Mean & 30.82 & 35.87 & 33.11 & 5.05 & 0.013 \\
\hline & SD & 22.32 & 26.87 & 24.6 & & \\
\hline \multirow[t]{3}{*}{ Mutual and Pension Funds } & $\mathrm{N}$ & 321 & 109 & 430 & & \\
\hline & Mean & 41.88 & 44.97 & 42.67 & 3.09 & 0.273 \\
\hline & SD & 29.92 & 30.55 & 30.08 & & \\
\hline \multirow[t]{3}{*}{ Government } & $\mathrm{N}$ & 105 & 122 & 227 & & \\
\hline & Mean & 54.06 & 69.86 & 62.55 & 15.8 & 0.000 \\
\hline & SD & 30.3 & 21.07 & 26.88 & & \\
\hline \multirow[t]{3}{*}{ Others } & $\mathrm{N}$ & 134 & 76 & 210 & & \\
\hline & Mean & 36.34 & 44.41 & 39.26 & 8.07 & 0.027 \\
\hline & $\mathrm{SD}$ & 26.26 & 28.58 & 27.33 & & \\
\hline \multirow[t]{3}{*}{ Total } & $\mathrm{N}$ & 3,885 & 2,368 & 6,253 & & \\
\hline & Mean & 44 & 51.52 & 46.84 & 7.52 & 0.027 \\
\hline & $\mathrm{SD}$ & 26.21 & 26.71 & 26.65 & & \\
\hline Panel B. Free Float & & Non-Dual-Class Shares & Dual-Class Shares & Total & & \\
\hline \multirow[t]{3}{*}{ Free-Float } & $\mathrm{N}$ & 3,885 & 2,368 & 6,253 & & \\
\hline & Mean & 33.05 & 29.63 & 31.76 & -3.42 & 0.000 \\
\hline & SD & 33.05 & 29.63 & 31.76 & & \\
\hline
\end{tabular}


Aguilera, R. V., \& Haxhi, I. 2019. Comparative corporate governance in emerging markets. In R. Grosse \& K. Meyer (Eds), Oxford handbook on management in emerging markets. Oxford: Oxford University Press.

Aguilera, R. V., \& Jackson, G. 2003. The cross-national diversity of corporate governance: dimensions and determinants. Academy of Management Review, 28(3): 447-465.

Capaul, M. 2003. Corporate governance in Latin America. World Bank, Working Paper.

Gao, C., Zuzul, T., Jones, G., \& Khanna, T. 2017. Overcoming institutional voids: A reputational-based view of long-term survival. Strategic Management Journal, 38: 2147-2167.

Gompers, P.A., Ishii, J., \& Metrick, A. 2010. Extreme governance: An analysis of dual-class firms in the United States. Review of Financial Studies, 23(3): 1051-1088.

Kim, J., Matos, P., \& Xu, T. 2018. Multi-class shares around the world: The role of institutional investors. Working Paper.

Khanna, T., \& Palepu, K. 2010. Winning in emerging markets: A road map for strategy and execution. Boston: Harvard Business School Publishing.

Maury, B., \& Pajuste, A. 2011 . Private benefits of control and dual-class share unifications. Managerial and Decision Economics, 32(6): 355-369.

Perkins, S. 2019. The dominance of pyramidal business groups in Latin America persists. AlB Insights, 19(2): 18-21

\section{Endnote}

1 To be included in the sample, a firm should have, at least, five consecutive years of data. The table presents the average and standard deviation of control rights of the largest shareholders. It also reports the percentage of firms in each country that issue dual-class shares.
Ruth V. Aguilera (r.aguilera@northeastern.edu) is a Distinguished Professor at Northeastern University, a Visiting Professor at ESADE in her native Barcelona, and an AIB Fellow. She received her PhD from Harvard University and her research interests are in corporate governance and corporate social responsibility. She is a Senior Editor at Organization Science, an Associate Editor at CGIR, and a Consulting Editor at JIBS. She serves on the Board of Directors of the Strategic Management Society and the International Corporate Governance Society.

Luiz Ricardo Kabbach de Castro (Irkcastro@gmail.com) is an Assistant Professor and Director of the Group of Excellence in Family Firms at the University of São Paulo, and Associate Professor at the Universidad de Navarra, Spain where he teaches Strategy and Family Business Management. His research interests include corporate governance and strategy in emerging economies, in particular, in family firms.

Rafel Crespi-Cladera (rafel.crespi@uib.es) is a Full Professor in the Department of Business Administration at the Universitat de les Illes Balears (Spain). He holds the Banca March Family Business Chair. His research on corporate governance focuses on how ownership structures influence firms' governance practices. His research has been published, among others, in Strategic Management Journal, Family Business Review, Journal of Corporate Finance, and Journal of Banking and Finance.

continued from page 7

\section{References}

AméricaEconomía. 2018. Las mayores 500 empresas de Lationamerica. AmericaEconomia, June 15. https://www.americaeconomia. $\mathrm{com} /$ negocios-industrias/conozca-las-500-empresas-masgrandes-de-america-latina. Accessed February 13, 2018.

CIA. 2019. The world factbook. CIA. https://www.cia.gov/library/publications/the-world-factbook/. Accessed February 13, 2019.

Cuervo-Cazurra, A. 2016. Multilatinas as a source of new theoretical insights: The learning and escape drivers of international expansion. Journal of Business Research, 69(6): 1963-1972.

Cuervo-Cazurra, A. Inkpen, A., Musacchio, A., \& Ramaswamy, K. 2014. Governments as owners: State-owned multinational companies. Journal of International Business Studies, 45: 919-942.

Cuervo-Cazurra, A., Luo, Y., Ramamurti, R., \& Ang, S. H. 2018. The impact of the home country on internationalization. Journal of World Business, 53(5): 593-604.

UNCTAD. 2019. UNCTADStat. https://unctadstat.unctad.org/wds/ ReportFolders/reportFolders.aspx?sCS_ChosenLang=en. Accessed February 1, 2019.

\section{Endinotes}

1 See Cuervo-Cazurra (2016) and references there for an overview of multilatinas.

2 See a more detailed explanation of the influence of the home country on internationalization in Cuervo-Cazurra et al. (2018).

3 See Cuervo-Cazurra et al. (2014) for an overview of the theoretical explanations.

4 See AméricaEconomía (2018) for the list of firms.

Alvaro Cuervo-Cazurra (a.cuervocazurra@neu.edu) is a Professor of Global Strategy at Northeastern University. He received a Ph.D. from the Massachusetts Institute of Technology and an Honorary Doctorate from Copenhagen Business School. Alvaro is a Fellow of the Academy of International Business and co-editor of Global Strategy Journal. He studies the internationalization of firms, particularly emerging market multinationals; capability upgrading, focusing on technological capabilities; and governance issues, especially corruption in international business. 